\title{
PCR detection of Streptococcus mutans and $S$. sobrinus in dental plaque samples from Japanese pre-school children
}

\author{
MITSUGI OKADA, YOSHIKO SODA, FUMIKO HAYASHI, TAKAKO DOI, JUNJI SUZUKI, \\ KAZUO MIURA and KATSUYUKI KOZAI \\ Department of Pediatric Dentistry, Hiroshima University Faculty of Dentistry, Hiroshima, Japan
}

\begin{abstract}
Streptococcus mutans and $S$. sobrinus are associated with the development of dental caries. These bacteria were detected by PCR and then their presence was compared with the incidence of dental caries in 77 Japanese pre-school children. Plaque samples were collected from all erupted tooth sites in the subjects, aged 3-5 years old and each with primary dentition, with a sterile toothbrush. A dental examination was performed for dmft (decayed, missing, filled, total) with the WHO caries diagnostic criteria. In all subjects, the prevalence of $S$. mutans and $S$. sobrinus was $72.8 \%$ and $61.1 \%$, respectively; $19(24.7 \%)$ were positive for $S$. mutans alone, $10(13.0 \%)$ were positive for $S$. sobrinus alone, $37(48.1 \%)$ were positive for both $S$. mutans and $S$. sobrinus, and $11(14.3 \%)$ were negative for both $S$. mutans and $S$. sobrinus. The $\mathrm{dmft}$ scores of children positive for both $S$. mutans and $S$. sobrinus were significantly higher than those positive for $S$. mutans alone. These results indicate that children harbouring both $S$. mutans and $S$. sobrinus have a significantly higher incidence of dental caries than those with $S$. mutans alone.
\end{abstract}

\section{Introduction}

Mutans streptococci (Streptococcus mutans and $S$. sobrinus) are closely associated with the development of dental caries in man. These bacteria are the most common pathogens isolated from human dental plaque and their prevalence has been reported in epidemiological studies $[1,2]$. Some researchers have found that $S$. mutans is more prevalent than S. sobrinus in dental plaque samples $[3,4]$, whereas several epidemiological studies have shown that the prevalence of $S$. sobrinus is more closely associated with high caries activity $[5,6]$.

The primary differentiation of these cariogenic species has generally been based on their colonial morphology on mitis-salivarius (MS) or MS-bacitracin agar [7-9]. However, this conventional method is sometimes inaccurate, as well as time-consuming and laborious. Moreover, it has been reported that MS-bacitracin inhibits the growth of $S$. sobrinus to a greater extent than that of $S$. mutans $[10,11]$. Thus, it is of great importance to distinguish the presence of these two

Received 16 Oct. 2001; revised version received 8 Dec. 2001; accepted 13 Dec. 2001.

Corresponding author: Dr M. Okada (e-mail: mitsugi@ hiroshima-u.ac.jp). species separately in children for accurate prediction and effective prevention of dental caries.

Various methods have been used for the detection of putative pathogens, including direct microscopy, cultivation, enzyme tests, enzyme-linked immunosorbent assays and species-specific DNA probes. It is now widely accepted that PCR methodology provides a more sensitive means of detection of putative bacteria species, when compared with conventional culture techniques [12-14], as it is able to detect low numbers of bacterial species with a detection limit of as few as 25-100 cells $[12,14,15]$, while being quick and relatively simple to perform. Moreover, a PCR assay has been found to be suitable for the specific detection and identification of human cariogenic bacteria, such as S. mutans and S. sobrinus $[12,14-16]$.

The purpose of this study was to detect $S$. mutans and $S$. sobrinus by PCR, and to compare their presence with the incidence of dental caries in pre-school children.

\section{Materials and methods}

Seventy-seven Japanese pre-school children, aged 3-5 years old and each with primary dentition, who were 
visitors to Hiroshima University Dental Hospital were enrolled. Consent for participation was obtained from at least one of their parents before the study according to the ethical guidelines of the Declaration of Helsinki (1975). The subjects received a dental examination by two well-trained paediatric dentists (YS and TD) while seated in a dental chair. The WHO caries diagnostic criteria were used for determining the $\mathrm{dmft}$ (decayed, missing, filled, total) index [17]. Those who had taken antibiotics within the previous 3 months or with systemic diseases were excluded. The agreement between the examining dentists was $>90 \%$ for interexaminer reproducibility for $\mathrm{dmft}$ criteria in a sample of 20 of the subjects.

\section{Plaque sampling}

Dental plaque was collected by brushing all erupted teeth with a sterile toothbrush for $1 \mathrm{~min}$ as described previously [18]. Plaque adhering to the toothbrush was removed by washing several times in a tube of sterile distilled water. The plaque samples were immediately transported to the laboratory and stored at $-20^{\circ} \mathrm{C}$, before extraction of genomic DNA.

\section{PCR}

S. mutans JCM5175 ${ }^{\mathrm{T}}$ and S. sobrinus ATCC $27607^{\mathrm{T}}$ were used as controls. PCR detection of tested species was performed with the primers described by Igarashi et al. $[12,15]$, while that of $16 \mathrm{~S}$ ribosomal DNA was done by the method of Goncharoff et al. [19].

Plaque samples were first harvested by centrifugation at $1600 \mathrm{~g}$ for $20 \mathrm{~min}$. The supernate were discarded and individual cell pellets were stored at $-20^{\circ} \mathrm{C}$ until DNA isolation. The genomic DNA preparation from each plaque sample was obtained by a standard miniprep procedure [20], with the additon of an RNAase treatment [21]. DNA concentrations in the dental plaque samples were calculated by measuring $A_{260}$, and the quality was estimated by the $A_{260} / A_{280}$ ratio [22].

PCR amplification was performed in a reaction mixture $(25 \mu \mathrm{l})$ consisting of PCR beads (Amersham Pharmacia Biotech, AB, Uppsala, Sweden) that contained an enzyme and the required reagents, $25 \mathrm{pmol}$ of each primer and $20-50 \mathrm{ng}$ of the template DNA solution in a thermal cycler (Program Temp Control System PC700, ASTEC, Fukuoka, Japan). Positive and negative controls were included in each PCR set and for all sample processing. The reaction mixture was denatured at $95^{\circ} \mathrm{C}$ for $3 \mathrm{~min}$ followed by a series of amplifications: denaturation at $95^{\circ} \mathrm{C}$ for $1 \mathrm{~min}$, annealing at $55^{\circ} \mathrm{C}$ for $1 \mathrm{~min}$ and extension at $72^{\circ} \mathrm{C}$ for $1 \mathrm{~min}$. The series was repeated for 26 cycles. The final cycle comprised $94^{\circ} \mathrm{C}$ for $1 \mathrm{~min}, 55^{\circ} \mathrm{C}$ for $1 \mathrm{~min}$ and $72^{\circ} \mathrm{C}$ for $5 \mathrm{~min}$ [12]. After amplification, $15 \mu 1$ of the PCR products were analysed by electrophoresis on an agarose 1.2\% gel. The newly synthesised DNA fragments were visualised under ultraviolet light at $302 \mathrm{~nm}$ after staining with ethidium bromide. The size of the PCR products was estimated from the electrophoretic migration of products relative to a 100-bp ladder (Amersham Pharmacia Biotech, AB, Uppsala, Sweden).

\section{Statistical analysis}

The Mann-Whitney U-test was employed for the caries score. A standard computer programme was used for statistical analysis (Statview; Abacus Concepts, Berkeley, CA 94704, USA).

\section{Results}

Table 1 shows the distribution of $S$. mutans and $S$. sobrinus in different age groups. In all subjects, the prevalence was $72.8 \%$ and $61.1 \%$, respectively; 19 (24.7\%) were positive for S. mutans alone, $10(13.0 \%)$ were positive for $S$. sobrinus alone, 37 (48.1\%) were positive for both $S$. mutans and S. sobrinus, and 11 $(14.3 \%)$ were negative for both $S$. mutans and $S$. sobrinus.

The caries prevalence in children with only $S$. mutans, or S. mutans and S. sobrinus, as related to the age of detection, is shown in Table 2. Overall, the $\mathrm{ft}$ and $\mathrm{dmft}$ scores of children positive for both $S$. mutans and $S$. sobrinus were significantly higher than those positive for $S$. mutans alone $(\mathrm{p}<0.05, \mathrm{p}<0.01$, respectively). In the 3-year-old age group, the $\mathrm{dmft}$ score of children positive for both $S$. mutans and $S$. sobrinus was significantly higher than those positive for $S$. mutans alone $(\mathrm{p}<0.05)$. PCR analysis with $16 \mathrm{~S}$ rDNA primers confirmed the presence of bacteria in all plaque samples (data not shown).

Table 1. Distribution of mutans streptococci in different age groups

\begin{tabular}{|c|c|c|c|c|c|}
\hline \multicolumn{2}{|c|}{ Organisms present } & \multicolumn{4}{|c|}{ Number $(\%)$ of subjects aged } \\
\hline S. mutans & S. sobrinus & 3 years & 4 years & 5 years & Total \\
\hline+ & - & $7(31.8)$ & $5(20.8)$ & 7 (22.6) & $19(24.7)$ \\
\hline+ & + & $11(50.0)$ & $10(41.7)$ & $16(51.6)$ & $37(48.1)$ \\
\hline - & + & $2(9.1)$ & $5(20.8)$ & $3(9.7)$ & $10(13.0)$ \\
\hline- & - & $2(9.1)$ & $4(16.7)$ & $5(16.1)$ & $11(14.3)$ \\
\hline \multicolumn{2}{|c|}{ Total } & 22 & 24 & 31 & 77 \\
\hline
\end{tabular}


Table 2. Caries prevalence in children with $S$. mutans alone or both $S$. mutans and S. sorbinus, related to the age at detection

\begin{tabular}{|c|c|c|c|c|c|c|c|}
\hline \multirow[b]{2}{*}{ Age (years) } & \multirow[b]{2}{*}{$\mathrm{n}$} & \multicolumn{2}{|c|}{ Mean (SD) dt } & \multicolumn{2}{|c|}{ Mean (SD) $\mathrm{ft}$} & \multicolumn{2}{|c|}{ Mean (SD) dmft } \\
\hline & & S. mutans & $\begin{array}{l}\text { S. mutans }+ \\
\text { S. sobrinus }\end{array}$ & S. mutans & $\begin{array}{l}\text { S. mutans }+ \\
\text { S. sobrinus }\end{array}$ & S. mutans & $\begin{array}{l}\text { S. mutans }+ \\
\text { S. sobrinus }\end{array}$ \\
\hline 3 & 22 & $0.86(1.22)$ & $1.18(1.17)$ & $3.14(3.24)$ & $7.73(4.82)^{*}$ & $4.00(3.11)$ & $8.91(4.81)^{*}$ \\
\hline 4 & 24 & $0.40(0.89)$ & $2.60(3.27)$ & $6.80(5.89)$ & $6.50(4.91)$ & $7.40(5.73)$ & $9.20(4.34)$ \\
\hline 5 & 31 & $0.29(0.76)$ & $0.75(1.01)$ & $6.14(3.53)$ & $8.81(4.64)$ & $6.43(3.60)$ & $9.88(4.53)$ \\
\hline Total & 77 & $0.53(0.96)$ & $1.38(2.03)$ & $5.21(4.25)$ & $7.87(4.73)$ & $5.79(4.12)$ & $9.41(4.46)^{\dagger}$ \\
\hline
\end{tabular}

Statistical significance; ${ }^{*} \mathrm{p}<0.05,{ }^{\dagger} \mathrm{p}<0.01$.

Table 3 shows PCR results obtained from the 13 $(16.9 \%)$ children who were free from caries. Of these, two had only $S$. mutans, four had only S. sobrinus, one had both, and six had neither.

\section{Discussion}

Transmission of and colonisation by mutans streptococci in the oral cavity are important factors for prevention of dental caries. Most children receive the organisms from their mothers [23-26]. Furthermore, Straetemans et al. [27] have suggested that delayed acquisition of mutans streptococci may reduce the incidence of caries in both primary and permanent dentition at later ages. Moreover, acquisition of mutans streptococci has been found to be most common during a discrete window period that occurs at around the age of 26 months [28]. Therefore, it is of great importance to detect the presence of mutans streptococci in early years for dental caries prediction and subsequent treatment. The PCR method used to detect $S$. mutans and $S$. sobrinus with $16 \mathrm{~S}$ rDNA primers confirmed the presence of bacteria in all positive plaque samples in the present study (data not shown). This tool provides a more sensitive means of detection of cariogenic bacterial species, as compared with conventional culture techniques [12, 15, 29].

The results of the present study indicated that the prevalence of mutans streptococci in 3-, 4- and 5-year-

Table 3. PCR results from caries-free children

\begin{tabular}{|c|c|c|c|c|c|}
\hline $\begin{array}{l}\text { Subject } \\
\text { no. }\end{array}$ & Sex & $\begin{array}{c}\text { Age } \\
\text { (years, } \\
\text { months) }\end{array}$ & S. mutans & S. sobrinus & rDNA \\
\hline 1 & Male & 3,0 & + & - & + \\
\hline 2 & Male & 3,1 & + & + & + \\
\hline 3 & Female & 3,3 & - & - & + \\
\hline 4 & Male & 3,7 & - & - & + \\
\hline 5 & Male & 4,0 & - & - & + \\
\hline 6 & Male & 4,1 & - & + & + \\
\hline 7 & Male & 4,1 & - & - & + \\
\hline 8 & Male & 4,1 & - & + & + \\
\hline 9 & Male & 4,11 & - & + & + \\
\hline 10 & Male & 4,11 & - & + & + \\
\hline 11 & Male & 4,9 & - & - & + \\
\hline 12 & Male & 5,1 & - & - & + \\
\hline 13 & Male & 5,8 & + & - & + \\
\hline
\end{tabular}

olds was $85.7 \%, 72.8 \%$ and $61.1 \%$, respectively, which is in agreement with other surveys of pre-school children [30-32]. The percentage of children positive for only $S$. mutans, or both $S$. mutans and S. sobrinus, was similar in each age group. It has been suggested that these bacteria are generally established in the oral cavity of children before 3 years of age; however, the present study found that $13.0 \%$ of all the children had S. sobrinus only, while $48.1 \%$ had both $S$. mutans and S. sobrinus. Köhler et al. [30] reported that S. sobrinus was usually found in combination with $S$. mutans in 4year-old pre-school children, except for two subjects in whom $S$. sobrinus was the only species detected. Dissimilar observations have been made in other populations $[33,34]$. Also, it has been reported that mitis-salivarius bacitracin inhibits the growth of $S$. sobrinus more than that of $S$. mutans $[10,11]$. The inconsistencies among these studies and the present study might be due in part to the detection methods employed or the ethnic backgrounds of the study subjects. Finally, the results of the present study suggest that the PCR method is suitable for investigation of the intra-oral distribution of $S$. sobrinus as well as $S$. mutans.

PCR results of the present study showed that children with both $S$. mutans and $S$. sobrinus had a significantly higher prevalence of caries than those with only $S$. mutans, which agrees with the results of a previous study by Köhler et al. [30]. They suggested that the presence of both $S$. mutans and $S$. sobrinus is associated with a significantly higher caries prevalence than $S$. mutans alone in pre-school children, although the subject population in their test was limited. Furthermore, in other reports, children with multiple species had high numbers of total mutans streptococci [30, 31, 33, 35]; however, Thomson et al. [36] suggested that the establishment of $S$. sobrinus in the presence of $S$. mutans occurred only in association with a high sucrose-containing diet.

In the present study there was no significant difference in the number of untreated decayed teeth between children positive for $S$. mutans alone and those with both $S$. mutans and $S$. sobrinus. Cross-sectional studies such as this one may not reveal considerable distinctions, whereas longitudinal ones may be expected to 
show significant differences between dental caries levels and a combination of mutans streptococci. Furthermore, in the present findings the $d$ (decayed) component was low, as all decayed teeth were immediately filled and therefore included in the $f$ (filled) component during dental check-ups that occurred at intervals of every few months to 6 months. Indeed, the score of decayed teeth tended to be lower according to increasing age. Longitudinal studies are required to evaluate the acquisition and colonising combination of mutans streptococci in the oral cavity of children, and to compare the results to the incidence of dental caries.

In the present study, $13(16.9 \%)$ of 77 children were caries-free; however, 7 (53.8\%) of those had either $S$. mutans or $S$. sobrinus alone, and one had both bacterial species. Matee et al. [37] reported high levels of mutans streptococci in some caries-free children. They also suggested that $S$. sobrinus did not seem to play a major role in the children aged $1-2.5$ years with rampant caries. Mattos-Graner et al. [38] suggested that the ability to synthesise water-insoluble glucan is an important virulence factor in initial caries development, in that it increases mutans streptococcal adherence and accumulation in the plaque of young children. Grönroos et al. [39] found that the mutacin activity of clinical isolates is reasonably stable, and this virulence factor seems to be of clinical importance in early colonisation by $S$. mutans. An understanding of the route of transmission of mutans streptococci may help clinicians to develop measures to prevent, delay, or reduce colonisation, thereby decreasing caries incidence [27, 40, 41].

In conclusion, the results of the present study indicate that children harbouring both $S$. mutans and $S$. sobrinus had a significantly higher incidence of dental caries than those positive for $S$. mutans alone.

We thank Dr Makoto Kawamura of Hiroshima University Faculty of Dentistry for special statistical advice on this work.

\section{References}

1. Hamada S, Slade HD. Biology, immunology, and cariogenicity of Streptococcus mutans. Microbiol Rev 1980; 44: 331-384.

2. Whiley RA, Beighton D. Current classification of the oral streptococci. Oral Microbiol Immunol 1998; 13: 195-216.

3. Loesche WJ. Role of Streptococcus mutans in human dental decay. Microbiol Rev 1986; 50: 353-380

4. Carlsson P, Gandour IA, Olsson B, Rickardsson B, Abbas K High prevalence of mutans streptococci in a population with extremely low prevalence of dental caries. Oral Microbiol Immunol 1987; 2: 121-124.

5. Fujiwara T, Sasada E, Mima N, Ooshima T. Caries prevalence and salivary mutans streptococci in 0-2-year-old children of Japan. Community Dent Oral Epidemiol 1991; 19: 151-154.

6. Hirose H, Hirose K, Isogai E, Miura H, Ueda I. Close association between Streptococcus sobrinus in the saliva of young children and smooth-surface caries increment. Caries Res 1993; 27: 292-297.

7. Gold OG, Jordan HV, van Houte J. A selective medium for Streptococcus mutans. Arch Oral Biol 1973; 18: 1357-1364.
8. Wade WG, Aldred MJ, Walker DM. An improved medium for isolation of Streptococcus mutans. J Med Microbiol 1986; 22 319-323.

9. Svanberg M, Krasse B. Comparative recovery of mutans streptococci on two selective media. Caries Res 1990; 24 $36-38$.

10. Jordan HV. Cultural methods for the identification and quantitation of Streptococcus mutans and lactobacilli in oral samples. Oral Microbiol Immunol 1986; 1: 23-30.

11. de Soet JJ, van Dalen PJ, Pavicic MJAMP, de Graaff J. Enumeration of mutans streptococci in clinical samples by using monoclonal antibodies. J Clin Microbiol 1990; 28 2467-2472.

12. Igarashi T, Yamamoto A, Goto N. PCR for detection and identification of Streptococcus sobrinus. J Med Microbiol 2000; 49: 1069-1074.

13. Ono T, Hirota K, Nemoto K, Fernandez EJ, Ota F, Fukui K. Detection of Streptococcus mutans by PCR amplification of spaP gene. J Med Microbiol 1994; 41: 231-235.

14. Oho T, Yamashita Y, Shimazaki Y, Kushiyama M, Koga T. Simple and rapid detection of Streptococcus mutans and Streptococcus sobrinus in human saliva by polymerase chain reaction. Oral Microbiol Immunol 2000; 15: 258-262.

15. Igarashi T, Yamamoto A, Goto N. Direct detection of Streptococcus mutans in human dental plaque by polymerase chain reaction. Oral Microbiol Immunol 1996; 11: 294-298.

16. Shiroza T, Shinozaki N, Watanabe T, Ikemi T, Fukushima K, Abiko Y. Rapid isolation of chromosomal DNA from oral streptococci and polymerase chain reaction-oriented restriction fragment-length polymorphism analysis for genetic heterogeneity. Oral Microbiol Immunol 1998; 13: 11-16.

17. World Health Organization. Individual tooth status and treatment need. In: Oral Health Surveys: Basic Methods, 3rd edn. Geneva, Switzerland, World Health Organization. 1987: 34-39

18. Okada M, Hayashi F, Nagasaka N. Detection of Actinobacillus actinomycetemcomitans and Porphyromonas gingivalis in dental plaque samples from children 2 to 12 years of age. $J$ Clin Periodontol 2000; 27: 763-768.

19. Goncharoff P, Figurski DH, Stevens RH, Fine DH. Identification of Actinobacillus actinomycetemcomitans: polymerase chain reaction amplification of $1 \mathrm{ktA}$-specific sequences. Oral Microbiol Immunol 1993; 8: 105-110.

20. Wilson K. Preparation of genomic DNA from bacteria. In: Ausubel FM et al. (eds) Current protocols in molecular biology, New York, Greene Pub. Assoc and Wiley Interscience. 1990: 2.4.1-2.4.2

21. Smith GL, Socransky SS, Smith CM. Rapid method for the purification of DNA from subgingival microorganisms. Oral Microbiol Immunol 1989; 4: 47-51.

22. Sambrook J, Fritsch EF, Maniatis T. Molecular cloning: a laboratory manual, 2nd edn, vol 3. Cold Spring Harbor NY, Cold Spring Harbor Laboratory. 1989: E.5.

23. Alaluusua S, Mätto J, Grönroos L et al. Oral colonization by more than one clonal type of mutans streptococcus in children with nursing-bottle dental caries. Arch Oral Biol 1996; 41: $167-173$

24. Caufield PW, Walker TM. Genetic diversity within Streptococcus mutans evident from chromosomal DNA restriction fragment polymorphisms. J Clin Microbiol 1989; 27: 274-278.

25. Li Y, Caufield PW. The fidelity of initial acquisition of mutans streptococci by infants from their mothers. J Dent Res 1995 74: $681-685$.

26. Russell RRB. The application of molecular genetics to the microbiology of dental caries. Caries Res 1994; 28: 69-82.

27. Straetemans MME, van Loveren C, de Soet JJ, de Graaff J, ten Cate JM. Colonization with mutans streptococci and lactobacilli and the caries experience of children after the age of five. $J$ Dent Res 1998; 77: 1851-1855.

28. Caufield PW, Cutter GR, Dasanayake AP. Initial acquisition of mutans streptococci by infants: evidence for a discrete window of infectivity. J Dent Res 1993; 72: 37-45.

29. Ono T, Hirota K, Nemoto K, Fernandez EJ, Ota F, Fukui K. Detection of Streptococcus mutans by PCR amplification of spaP gene. J Med Microbiol 1995; 41: 231-235.

30. Köhler B, Andréen I, Jonsson B. The earlier the colonization by mutans streptococci, the higher the caries prevalence at 4 years of age. Oral Microbiol Immunol 1988; 3: 14-17.

31. Li Y, Navia JM, Caufield PW. Colonization by mutans 
streptococci in the mouths of 3- and 4-year-old Chinese children with or without enamel hypoplasia. Arch Oral Biol 1994; 39: 1057-1062.

32. Köhler B, Bjarnason S, Care R, Mackevica I, Rence I. Mutans streptococci and dental caries prevalence in a group of Latvian preschool children. Eur J Oral Sci 1995; 103: 264-266.

33. Köhler B, Bjarnason S, Finnbogason SY, Holbrook WP. Mutans streptococci, lactobacilli and caries experience in 12-year-old Icelandic urban children, 1984 and 1991. Community Dent Oral Epidemiol 1995; 23: 65-68.

34. Masuda N, Tsutsumi N, Sobue S, Hamada S. Longitudinal survey of the distribution of various serotypes of Streptococcus mutans in infants. J Clin Microbiol 1979; 10: 497-502.

35. Köhler B, Bjarnason S. Mutans streptococci, lactobacilli and caries prevalence in 11- and 12-year-old Icelandic children. Community Dent Oral Epidemiol 1987; 15: 332-335.

36. Thomson LA, Little WA, Bowen WH, Sierra LI, Aguirrer M, Gillespie G. Prevalence of Streptococcus mutans serotypes, Actinomyces, and other bacteria in the plaque of children. $J$ Dent Res 1980; 59: 1581-1589.
37. Matee MIH, Mikx FHM, Maselle SYM, Van Palenstein Helderman WH. Mutans streptococci and lactobacilli in breast-fed children with rampant caries. Caries Res 1992; 26: $183-187$.

38. Mattos-Graner RO, Smith DJ, King WF, Mayer MPA. Waterinsoluble glucan synthesis by mutans streptococcal strains correlates with caries incidence in 12- to 30-month-old children. J Dent Res 2000; 79: 1371-1377.

39. Grönroos L, Saarela M, Mättö J, Tanner-Salo U, Vuorela A, Alaluusua S. Mutacin production by Streptococcus mutans may promote transmission of bacteria from mother to child. Infect Immun 1998; 66: 2595-2600.

40. Köhler B, Andréen I. Influence of caries-preventive measures in mothers on cariogenic bacteria and caries experience in their children. Arch Oral Biol 1994; 39: 907-911.

41. Tenovuo J, Hakkinen P, Paunio P, Emilson CG. Effects of chlorhexidine-fluoride gel treatments in mothers on the establishment of mutans streptococci in primary teeth and the development of dental caries in children. Caries Res 1992; 26: $275-280$. 